\title{
UJI EFIKASI BERBAGAI DOSIS PUPUK KOTORAN HEWAN DAN VOLUME AIR TERHADAP PERTUMBUHAN BIBIT KLON S-1 TANAMAN KAKAO (Theobroma Cacao L.)
}

\author{
Syarifuddin $^{1}$, Rati Tarpono ${ }^{2}$ \\ ${ }^{1}$ Staf pengajar pada MTs Nurul Ikhlas Ambon \\ ${ }^{2}$ Program Studi Pendidikan Biologi FITK IAIN Ambon \\ E-mail: syarifuddin@yahoo.co.id
}

\begin{abstract}
Abstrak: Penelitian ini dilaksanakan selama 3 (tiga) bulan sejak tahap persiapan sampai selesai pengamatan dari bulan Juli sampai September 2015 yang berlokasi di Jln. Lorong Putri, RT/RW 005/019, Desa Batumerah, Kota Ambon, Provinsi Maluku. Penelitian ini disusun dalam Rancangan Acak Lengkap (RAL) dalam pola faktorial yang terdiri dari: Faktor pertama adalah jenis pupuk kotoran hewan yang terdiri dari pupuk kotoran ayam (K1), sapi (K2), dan kambing (K3). Faktor kedua adalah dosis (D) masing-masing terdiri dari 4 taraf perlakuan yaitu D0 $=0$ tha $^{-1}$ (Kontrol), D1 $=5$ tha $^{-1}, \mathrm{D} 2=10$ tha $^{-1}, \mathrm{D} 3=15 \mathrm{tha}^{-1}$. Faktor ketiga adalah volume air (V) yang terdiri dari 4 taraf perlakuan, yaitu V0 $=0 \mathrm{ml}$ (Kontrol), V1 $=20 \mathrm{ml}, \mathrm{V} 2=40 \mathrm{ml}$, dan V3 $=60$ ml. Analisis data penelitian menggunakan bantuan komputer Program SPSS ver. 19.0 for Windows. Untuk pengujian hipotesis berdasarkan Analysis of Variance (ANOVA) dengan membandingkan nilai probabilitas dengan $\alpha=0.05$. Jika nilai probabilitas $\leq 0.05$ $(\mathrm{p} \leq 0.05)$ maka disimpulkan perlakuan berpengaruh secara signifikan dan apabila nilai probabilitas > $0.05(\mathrm{p}>0.05)$ maka disimpulkan perlakuan tdak berpengaruh secara signifikan. Perlakuan yang memberikan pengaruh signifikan dilakukan uji beda LSD dan uji lanjut dengan menggunakan Uji Lanjut Duncan taraf kepercayaan 95\%. Hasil penelitian menunjukkan bahwa : (1) Tidak terdapat pengaruh interaksi antara dosis pupuk kotoran ayam, sapi, maupun kambing dengan volume air terhadap pertumbuhan bibit tanaman $\operatorname{kakao}(T$. cacao L.) umur 42 HST karena diduga terjadi pencucian unsur hara dalam pupuk kotoran hewan akibat tidak seimbang antara ukuran polybag dengan volume air siraman. (2) Tidak terdapat pengaruh dosis pupuk kotoran ayam, sapi, maupun kambing terhadap pertumbuhan bibit tanaman kakao (T. cacao L.) umur 42 HST. Tetapi berdasarkan nilai rata-rata dari hasil Uji Lanjut Duncan taraf kepercayaan 95\% terlihat bahwa dosis 5 tha $^{-1}$ memiliki nilai rata-rata tertinggi terhadap variabel tinggi tanaman, jumlah daun, dan panjang akar tunggang, ika dibandingkan dengan dosis 10 tha $^{-1}$ dan 15 tha $^{-1}$. Hal ini diduga karena baru pertumbuhan awal pada bibit tanaman kakao (T. cacao L.) umur 42 HST sehingga belum banyak membutuhkan unsur hara, sehingga dosis 5 tha $^{-1}$ diduga telah sesuai kebutuhan pertumbuhan bibit tanaman kakao (T. cacao L.) umur 42 HST. (3) Terdapat pengaruh yang signifikan perlakuan volume air terhadap pertumbuhan bibit tanaman kakao (T. cacao L.) umur 42 HST karena diduga bibit tanaman kakao telah mampu menyerap air dengan baik untuk proses metabolisme. Kemudian berdasarkan Uji Lanjut Duncan disimpulkan tidak ada perbedaan perlakuan antara volume air $20 \mathrm{ml}, 40 \mathrm{ml}$, dan $60 \mathrm{ml}$ kecuali dengan kontrol. Tetapi berdasarkan nilai rata-rata, maka dapat dinyatakan bahwa volume air $20 \mathrm{ml}$
\end{abstract}

BIOLOGI SEL (VOL 7 NO 1 EDISI JAL-JUL 2018 ISSN 2252-858X/E-ISSN 2541-1225) PAGE 64 
memiliki nilai rata-rata tertinggi pada variabel tinggi tanaman dan jumlah daun, sehingga dapat dinyatakan bahwa volume $20 \mathrm{ml}$ yang paling baik untuk pertumbuhan bibit tanaman kakao klon Sulawesi-1 (S-1).

\title{
Kata Kunci: T. cacao L. Klone S-1, Dosis Pupuk Kotoran Hewan, Volume Air \\ EFFICACY TESTING of DIFFERENT DOSE FERTILIZE DIRT ANIMALS and VOLUME IRRIGATE the GROWTH of COCOA SEEDS at CLONE of S-1 (Theobroma Cocoa L.)
}

\begin{abstract}
Abstrack: The study was conducted for three (3) months from the preliminary stage to complete the observation starting from July to September 2015, located at Jln. Lorong Putri, RT /RW 005 / 019, Batumerah Village, City of Ambon, Maluku province. This research is compiled in a Complete Randomized Design (CRD) in a factorial design consisting of: The first factor is types dirt animals, chicken dirt (K1), cow (K2), and goat (K3). The second factor is dose (D) each consisting of 4 treatment level that is D0 $=0$ tha $^{-1}$ (Control), D1 $=5$ tha $^{-1}, \mathrm{D} 2=10 \mathrm{tha}^{-1}, \mathrm{D} 3=15 \mathrm{tha}^{-1}$. The third factor is water volume (V) which consist of 4 level of treatment, i.e V0 $=0 \mathrm{ml}$ (Control), V1 $=20 \mathrm{ml}$, $\mathrm{V} 2=40 \mathrm{ml}$, and V3 $=60 \mathrm{ml}$. Data analysis of the study used SPSS ver. 19.0 for Windows. To test hypothesis based on the Analysis of Variance (ANOVA) by comparing probability value with $\alpha=0.05$. If probability value $\leq 0.05(\mathrm{p} \leq 0.05)$, it is conclused the treatment significant effect and if probability value $>0.05(\mathrm{p}>0.05)$, it is conlused treatment had no significant effect. The treatments have a significant impact to testing mean different by using Test's LSD and Duncan at level of 95\%. The result of the study showed that: (1) There is no influence of interaction between dose fertilize chicken dirt, the cow, and the goat with volume irrigate the growth of the cocoa seed $(T$. cacao L.) age 42 HST because anticipated to happened wash of element of nutrient in uneven effect animals dirt manure between size measure of polybag with volume irrigate. (2) There is no influence of dose fertilize chicken dirt, cow, and goat the growth of the cocoa seed (T. cocoa L.) age 42 HST. But pursuant to average value from result of Test's Duncan at level of $95 \%$ showed that dose 5 tha $^{-1}$ have highest average value to long variable and diametre of hipocotyl, high of crop, amount of leaf, wide of leaf, and root length ride, except bar diametre variable and leaf length in comparison with dose 10 tha $^{-1}$ and 15 tha $^{-1}$. It's because the growth early of the cocoa seed (T. cocoa L.) age $42 \mathrm{HST}$ so that not yet requiring many nutrients, so that dose 5 tha $^{-1}$ have according to requirement of the growth cocoa seed (T. cocoa L.) age 42 HST. (4) There is signifikan effect of the treatment volume irrigate the growth of the cocoa seed (T.cocoa L.) age 42 HST because seed of the cocoa crop have been able to permeate water better for the process of metabolism. Then pursuant to Test's Duncan concluded there is no difference of treatment between volume irrigate $20 \mathrm{ml}, 40 \mathrm{ml}$, and $60 \mathrm{ml}$ except with control. But based to average value that volume irrigate $20 \mathrm{ml}$ have highest average value at variable for high of crop and amount of leaf, so that can be conclused that volume $20 \mathrm{ml}$ the best treatment for the growth of the cocoa seed at clone of Sulawesi-1( S-1).
\end{abstract}

BIOLOGI SEL (VOL 7 NO 1 EDISI JAL-JUL 2018 ISSN 2252-858X/E-ISSN 2541-1225) PAGE 65 


\section{Keywords: T. cocoa L. at S-1 Clone, Dose Manure Dirt Animals, Volume Irrigate.}

Tanaman kakao (Theobroma cacao L.) merupakan salah satu komoditas perkebunan yang peranannya cukup penting bagi perekonomian nasional, khususnya sebagai penyedia lapangan kerja, sumber pendapatan dan devisa Negara. Tahun 2002, perkebunan tanaman kakao telah menyediakan lapangan kerja dan sumber pendapatan sekitar 900 ribu kepala keluarga petani yang sebagian besar berada di Kawasan Timur Indonesia (KTI) serta memberikan sumbangan devisa terbesar ke tiga sub sektor perkebunan setelah karet dan minyak sawit dengan nilai sebesar US \$ 701 juta (Departemen Perindustrian, 2007; Sugito, 2002 dalam Lestari et al, 2007). Menurut Hasniawati (2010) dalam Afriyeni et al (2013) bahwa Indonesia merupakan negara penghasil kakao terbesar nomor tiga di dunia, setelah Pantai Gading dan Ghana berdasarkan data tahun 2009 yang dikeluarkan oleh International Cocoa Organization (2009) dalam Burhanudin et al (2011) dengan produksi kakao Indonesia didunia sebesar 540 ribu ton, Ghana sebesar 680 ribu ton, dan Pantai Gading 1,22 juta ton. Disamping itu hasil olahan seperti cokelat bubuk, banyak dipakai sebagai bahan yang dapat diolah menjadi beranekaragam makanan dan minuman yang sehat dikomsumsi, seperti susu, selai, dan roti (Corti et al, 2009; ICN, 2010), juga buah tanpa biji dapat difermentasi untuk dijadikan pakan ternak (Nuraini dan Mahata, 2009) serta kulit buah tanaman kakao dapat diolah menjadi Bioetanol (Efendi, 2011), zat pewarna karena mengandung $\beta$-karoten (Wulan, 2001), dan serat selullosa pada pulp buah kakao sebagai bahan baku kertas (Harsini dan Susilowati, 2004).

Salah satu wilayah pengembangan lahan perkebunan tanaman kakao di Indonesia yang potensial adalah Provinsi Maluku dengan luas lahan yang sudah digunakan 24.932 ha atau baru memiliki sekitar $6 \%$ perkebunan tanaman kakao (ICN, 2010). Berdasarkan data BPS (2012) bahwa produksi tanaman kakao perkebunan rakyat, perkebunan Negara dan swasta di Provinsi Maluku lima tahun terakhir adalah sebagai berikut : Tahun 2008 produksi tanaman kakao 6.928 ton, tahun 2009 sebesar 8.544 ton, kemudian tahun 2010 sekitar 7.819 ton, sedangkan tahun 2011 naik menjadi 11.512 ton, kemudian turun pada tahun 2012 (dalam angka estimasi) sebesar 8.410 ton. Fluktuasi produksi kakao Provinsi Maluku lima tahun terkahir diperoleh rata-rata produksi sekitar 8.642 ton kemudian dibandingkan dengan jumlah produksi tanaman kakao secara nasional sebesar 2.501.200 ton (BPS, 2013), maka Provinsi Maluku baru menyumbang produksi tanaman kakao dalam skala nasional sekitar 3,45\%.

Salah satu faktor dalam budidaya tanaman kakao yang utama untuk diperhatikan adalah penggunaan bibit (Hendrata dan Sutardi, 2010). PUSLITLOKA (2010) dan Henrata dan Sutardi (2010) menjelaskan bahwa bibit tanaman kakao dapat diperoleh melalui pembiakan generatif maupun vegetatif, namun pembiakan generatif memiliki keuntungan, mudah dilakukan oleh petani, jumlah bibit tanaman kakao yang diperoleh 
lebih banyak, dan kemungkinan kegagalan relatif lebih rendah jika dibandingkan dengan pembiakan cara vegetatif seperti stek, cangkok, okulasi, dan kultur jaringan (Rokhiman dan Harjadi (1973) dalam Sutardi dan Hendrata (2009); Siregar dkk (1992) dalam Henrata dan Sutardi (2010); Tsobeng et al (2011); Hartman dan Kester (1983) dalam Tsobeng et al (2013). Bibit tanaman kakao yang telah diuji dan disertifikasi oleh Kementerian Pertanian diistilahkan dengan klon yang telah dijadikan subyek penelitian, antara lain klon DR1, DR2, dan DR38 sementara masih banyak klon tanaman kakao yang belum dikaji lebih mendalam dalam hal pembudidayaannya, seperti klon Sulawesi-1 (S1), Sulawesi-2 (S2), maupun Malaysia-01 (M01) (Sutardi dan Henrata (2009); Prawoto dan Martini, 2014). Ciri morfologi klon Sulawesi-1 (S1) yang menjadi subyek penelitian ini adalah buah berwarna merah dan memiliki pucuk daun muda berwarna merah berdasarkan SK Mentan No. 1694/Kpts/SR.120/12/2008 (Prawoto dan Martini, 2014).

Keberhasilan pembibitan tanaman kakao tidak terlepas dari faktor pemupukan sebagai upaya untuk menambah atau mengganti unsur hara pada media pertumbuhan tanaman karena menurut Adi et al. (1998) dan Sanchez (1982) dalam Sarno (2009) menjelaskan bahwa tanah-tanah di daerah tropik termasuk di Indonesia pada umumnya memiliki kandungan bahan organik rendah dan miskin unsur hara. Pupuk kotoran hewan dapat memperbaiki sifat fisika tanah, yaitu kapasitas tanah menahan air, kerapatan massa tanah dan porositas, memperbaiki stabilitas agregat tanah dan meningkatkan kandungan humus tanah (Slameto, 1997; Adi et al., 1998; Maet al., 1999; Martin et al, 2006; Wigati et al, 2006; Faesal et al, 2006; Taufiq et al, 2007 dalam Sarno, 2009) serta memberikan nilai konservasi pada tanah dalam jangka panjang (Aminudin dan Hendarto, 2000 dalam Hendarto dan Suwarso, 2013). Selain faktor pemupukan yang menjadi kendala dalam pembibitan tanaman kakao juga ditemukan masalah ketersediaan air sehingga dengan penambahan pupuk organik termasuk pupuk kotoran hewan ayam, sapi, maupun kambing akan mampu menahan air yang nantinya diserap melalaui akar tanaman kakao untuk mendukung pertumbuhan secara optimal (Wibawa dan Pujiyanto, 1989 dalam Henrata dan Sutardi, 2010).

Informasi mengenai dosis pupuk kotoran hewan dan volume air yang tepat untuk diaplikasikan terhadap pembibitan tanaman kakao masih jarang ditemukan ditingkat petani karena pada umumnya petani menggunakan tanah lapisan topsoil tanpa pupuk sebagai media pertumbuhan bibit tanaman kakao, sementara tanah lapisan topsoil semakin berkurang, sehingga perlu mencari media tumbuh alternatif, yakni penggunaan tanah lapisan subsoil, namun kendalanya tanah lapisan subsoil termasuk lapisan tanah yang minim kandungan unsur hara (Hendrata dan Sutardi, 2010). Apalagi dalam penelitian ini menggunakan tanah lapisan subsoil yang kandungan unsur hara sangat rendah, sehingga sangat tepat bila ditambahkan dengan pupuk kotoran hewan untuk menambah kesuburan media tumbuh bibit tanaman kakao (Suntoro, 2001). Disamping 
itu, menurut Astuti (2005) dan Eck et al (1990) dalam Hendarto dan Suwarso (2013) bahwa pupuk organik yang banyak tersedia dilingkungan masyarakat antara lain pupuk kotoran hewan, seperti ayam, sapi, dan kambing.

Oleh karena itu sangat menarik untuk melakukan pengkajian secara mendalam tentang pemanfaatan pupuk kotoran ayam, sapi maupun kambing serta volume air terhadap pertumbuhan bibit tanaman kakao. Di lain pihak, terbatasnya referensi jenisjenis klon tanaman kakao di Provinsi Maluku seperti pernyataan Karmawati et al (2010) bahwa di Provinsi Maluku pernah ditemukan 10.000 - 12.000 tanaman kakao dan telah menghasilkan 11,6 ton tapi tanamannya hilang tanpa informasi lebih lanjut, sementara tanaman kakao merupakan salah satu tanaman perkebunan unggulan Provinsi Maluku. Dengan dasar inilah penulis tertarik melakukan penelitian untuk uji efikasi berbagai dosis pupuk kotoran hewan serta volume air terhadap pertumbuhan bibit tanaman kakao (T.cacao L.) dalam upaya peningkatan kuantitas dan kualitas produksi tanaman kakao di Provinsi Maluku.

\section{METODE PENELITIAN}

Penelitian ini dilaksanakan selama 3 (tiga) bulan sejak tahap persiapan sampai selesai pengamatan dari bulan Juli sampai September 2015 yang berlokasi di Jln. Lorong Putri, RT/RW 005/019, Desa Batumerah, Kota Ambon, Provinsi Maluku. Variabel dalam penelitian ini terdiri dari variabel bebas (independent) meliputi dosis pupuk kotoran hewan dan volume air dan variabel terikat (dependent) meliputi tinggi tanaman, jumlah daun, dan panjang akar tunggang.

Penelitian ini disusun dalam Rancangan Acak Lengkap (RAL) dalam pola faktorial yang terdiri dari: Faktor pertama adalah jenis pupuk kotoran hewan yang terdiri pupuk kotoran ayam (K1), sapi (K2), dan kambing (K3). Faktor kedua adalah dosis masing-masing pupuk kotoran hewan (D) terdiri dari 4 taraf perlakuan, yaitu D0 = 0 tha $^{-1}$ atau 0 gram/polybag (Kontrol), D1 $=5$ tha $^{-1}$ setara dengan 3,75 gram/polybag, D2 $=10$ tha $^{-1}$ setara dengan 7,50 gram/polybag, D3 $=15$ tha $^{-1}$ setara dengan 11,25 gram/polybag. Faktor tiga adalah volume air (V) yang terdiri dari 4 taraf perlakuan, yaitu V0 = $0 \mathrm{ml}$ (Kontrol), V1 $=20 \mathrm{ml}, \mathrm{V} 2=40 \mathrm{ml}$, dan V3 $=60 \mathrm{ml}$. Dengan pola $3 \times 4$ $\mathrm{x} 4$, maka diperoleh 48 kombinasi perlakuan. Kemudian diulang 3 kali, sehingga diperoleh 48 × $3=144$ unit dalam penelitian. Cara melakukan konversi dosis pupuk kotoran hewan menggunakan formulasi sebagai berikut :

$$
\begin{gathered}
Y \text { tha }^{-1} \rightarrow \frac{Y x 1.000 \mathrm{~kg}}{\text { Berat Tanah } 1 \mathrm{ha}}=\frac{\text { Dosisyang dïnginkan }}{\text { Berat Tanah dalampolybag }} \\
\text { Dosis yang diinginkan }=\frac{Y x 1.000 \mathrm{~kg} x \text { Berat tanah dalampolybag }}{\text { Berat Tanah } 1 \mathrm{ha}}
\end{gathered}
$$

Model statistik untuk rancangan penelitian yang menggunakan pola faktorial dengan rancangan dasar RAL adalah sebagai berikut (Gaspersz, 1989):

BIOLOGI SEL (VOL 7 NO 1 EDISI JAL-JUL 2018 ISSN 2252-858X/E-ISSN 2541-1225) PAGE 68 
Dimana:

$$
\begin{aligned}
& \mathbf{Y}_{\mathbf{i j}}=\boldsymbol{\mu}+\mathbf{A}_{\mathbf{i}}+\mathbf{B}_{\mathbf{j}}+(\mathbf{A B})_{\mathbf{i j}}+\mathbf{E}_{\mathbf{i j}} \\
& \mathrm{i}=1, \ldots \ldots, \mathrm{a} \quad{ }_{j}=1, \ldots \ldots \ldots, b
\end{aligned}
$$

$\mathrm{Y}_{\mathrm{ij}} \quad=$ Nilai pengamatan yang diperoleh taraf ke-i dari faktor $\mathrm{A}$ (dosis pupuk kotoran hewan), dan taraf ke-j dari faktor B (Volume Air )

$\mu \quad=$ Nilai rata-rata pengamatan

$\mathrm{A}_{\mathrm{i}} \quad=$ Pengaruh aditif dari taraf ke-i faktor A (dosis pupuk kotoran hewan)

$\mathrm{B}_{\mathrm{j}} \quad=$ Pengaruh aditif dari taraf ke-j faktor B (Volume Air)

$(\mathrm{AB})_{\mathrm{ij}}=$ Pengaruh interaksi taraf ke-i faktor $\mathrm{A}$ (dosis pupuk kotoran hewan) dengan taraf ke-j faktor B (Volume Air )

$\varepsilon_{\mathrm{ij}} \quad=$ Pengaruh Galat taraf ke-i faktor A (dosis pupuk kotoran hewan), taraf ke-j faktor B (Volume Air )

Data yang diperoleh selama pengamatan dianalisis dengan statistik inferensial. Statistik inferensial menggunakan teknik ANOVA (Analsys of Variance) atau analisis sidik ragam dengan taraf kepercayaan $95 \%$ atau signifikansi $5 \%\left(\alpha_{0.05}\right)$. Pengolahan data dilakukan dengan bantuan komputer program SPSS 19.0 for Windows (Statistical Product and Service Solutions), kemudian output dari Program SPSS 19.0 dianalisis, jika nilai probabilitas $\leq 0.05(\mathrm{p} \leq 0.05)$ disimpulkan memberikan pengaruh secara signifikan, maka dilanjutkan dengan uji beda LSD dan Uji Lanjut Duncan dan tidak dilakukan uji lanjut jika nilai probabilitas $>0.05(\mathrm{p}>0.05)$.

\section{HASIL DAN PEMBAHASAN}

\section{Pengaruh Interaksi Dosis Pupuk Kotoran Hewan Dengan Volume Air}

Dari hasil analisis Two Way Anova menunjukkan bahwa nilai probabilitas $>0.05$ ( $\mathrm{p}>0.05$ ), maka dapat disimpulkan bahwa tidak terdapat interaksi antara dosis pupuk kotoran hewan baik pupuk kotoran ayam, sapi, maupun kambing dengan volume air terhadap variabel pengamatan yang meliputi tinggi tanaman, jumlah daun, dan panjang akar tunggang pada bibit tanaman kakao (T.cacao) umur 42 HST.

Hal ini diduga oleh volume air yang cukup besar dan tidak sebanding dengan ukuran polybag yang digunakan, sehingga terjadi proses pencucian hara yang terkandung di dalam pupuk kotoran hewan. Dugaan ini dapat dikonfirmasi dengan pernyataan Doorenbos dan Kassam (1979) dan Haryati (2003) dalam Dwiyana dkk (2015) menyatakan bahwa untuk mempercepat pertumbuhan tanaman perlu penyiraman air yang sesuai kebutuhan tanaman karena penggunaan air yang berlebihan dapat menyebabkan tanaman mengalami kekurangan unsur hara karena terjadinya pencucian. Pencucian unsur hara di dalam media atau tanah akan berdampak terhadap menurunnya kualitas dan kuantitas hara, sehingga jumlah hara yang terangkut melalui akar melalui 
proses penyerapan tidak sebanding dengan kebutuhan tanaman, dan hal ini akan berdampak langsung terhadap proses metabolisme tanaman (Sumarno, 1992).

Proses metabolisme tanaman yang mengalami gangguan akan berdampak terhadap pertumbuhan vegetatif seperti tanaman menjadi kerdil, bahkan kepada kematian (Sutedjo, 2002). Sebagai bahan perbandingan akan kebutuhan air tanaman dapat diperhatikan pernyataan AAK (1983) dalam Sumarno (1992) bahwa untuk menghasilkan enam ton butir jagung, tanaman harus menghasilkan 15 ton bahan kering (butiran jagung merupakan sepertiga dari seluruh tanaman). Bila tanaman menggunakan rata-rata 300 ton air untuk menghasilkan satu ton bahan kering, maka air yang dibutuhkan adalah $15 \times 300=4.500$ ton atau $4500 \mathrm{~m}^{3}$ air per hektar $( \pm 33,7 \mathrm{ml}$ dalam berat tanah 1,5 kg). Lebih lanjut dijelaskan oleh Lakitan (2008) dan Dwiyana $d k k$ (2015) bahwa pupuk organik merupakan sumber nutrisi esensial untuk pertumbuhan suatu tanaman. Pemberian pupuk yang sesuai dengan dosis kebutuhan tanaman akan berdampak kepada pertumbuhan vegetatif yang baik, begitu juga dengan pemberian volume air yang sesuai dengan kebutuhan tanaman akan mempercepat masa dormansi biji dan akan memperbaiki pertumbuhan vegetatif maupun generative (Mutryarny $d k k$, 2014).

\section{a. Pengaruh Dosis}

Analisis pengaruh dosis pupuk kotoran hewan dengan menggunakan teknik Anova satu jalur (One Way Anova). Berdasarka hasil analisis pengaruh dosis pupuk kotoran hewan terhadap pertumbuhan bibit tanaman kakao (T. cacaoL.) umur 42 HST dengan nilai probabilitas $>0.05(\mathrm{p}>0.05)$ maka disimpulkan tidak terdapat pengaruh dosis pupuk kotoran hewan terhadap variabel tinggi tanaman, jumlah daun, dan panjang akar tunggang bibit tanaman kakao (T.cacao) umur 42 HST. Namun berdasarkan perbedaan nilai rata-rata pada Homogeneous Subsets output SPSS ver. 19.0 for Windows dapat dilihat pada Gambar 1.

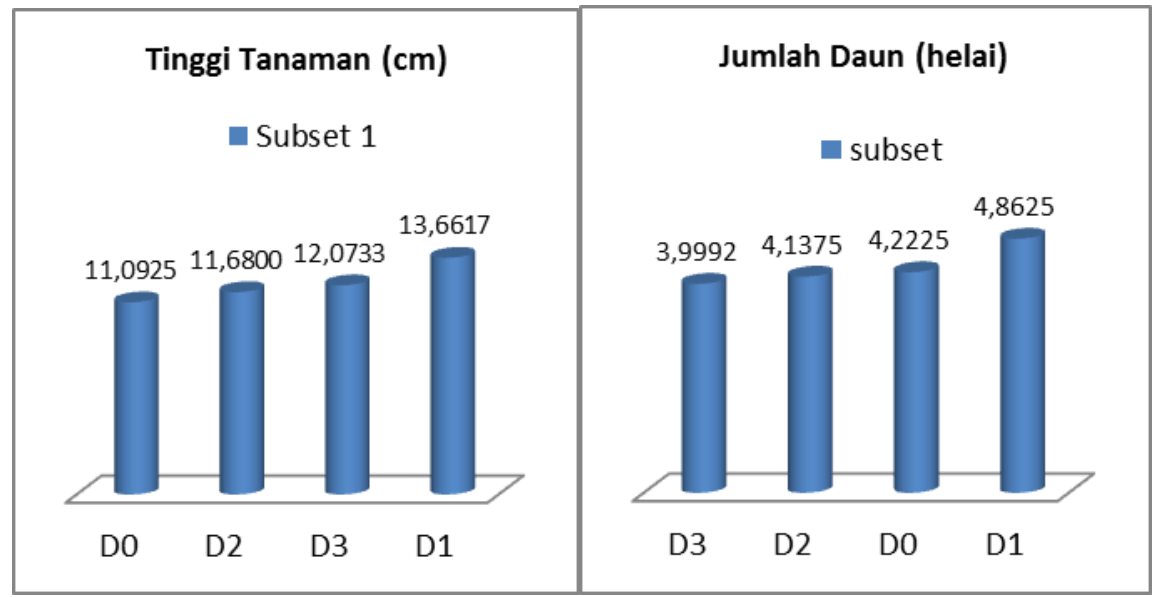

(a)

(b) 


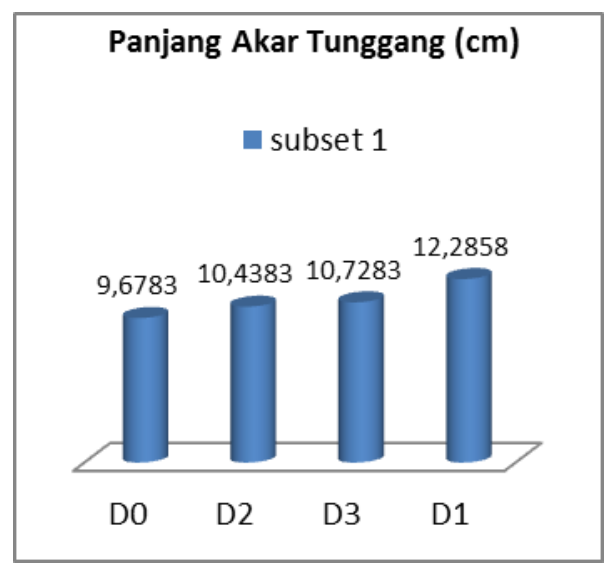

(c)

Gambar 1. Histogram Perbedaan Rata-rata pada Tinggi Tanaman (a) Jumlah Daun (b); dan Panjang Akar Tunggang (c)

Dari Gambar 1. memperlihatkan bahwa perlakuan D1atau dosis 5 tha $^{-1}$ memiliki nilai rata-rata tertinggi tinggi tanaman $(13.6617 \mathrm{~cm})$, jumlah daun (4.8625 helai daun), dan panjang akar tunggang $(12.2858 \mathrm{~cm})$ dibandingkan dengan perlakuan D2 atau dosis 10 tha $^{-1}$, D3 atau dosis 15 tha $^{-1}$. Sedangkan D0 atau kontrol $\left(0\right.$ tha $\left.^{-1}\right)$ memiliki rata-rata terendah pada variabel tinggi tanaman, panjang akar tunggang, kecuali jumlah daun dengan nilai rata-rata terendah pada pelakuan D3 atau dosis 15 tha $^{-1}$ (3.9992 helai daun).

Berdasarkan hasil rata-rata nilai subset dari hasil Uji Duncan taraf kepercayaan 95\%, maka hasil tersebut memberi asumsi bahwa aplikasi dosis 5 tha $^{-1}$ masih lebih baik dengan dosis 10 tha $^{-1}$ dan 15 tha $^{-1}$ hal ini cukup beralasan karena diduga pertumbuhan bibit tanaman kakao ( $T$. cacao L.) umur 42 HST masih tahap awal, sehingga membutuhkan unsur hara yang tidak terlalu banyak, serta cadangan makanan yang tersimpan pada kotiledon turut berperan dalam pertumbuhan bibit tanaman kakao yang mempunyai kemampuan melakukan fotosintesis. Hasil penelitian ini dapat dibandingkan dengan penelitian yang dilakukan oleh Maruapey (2011) selama 5 bulan dengan hasil bahwa dosis yang terbaik adalah 20 tha $^{-1}$ dibandingkan dengan 30 tha $^{-1}$ pada pupuk kotoran ayam yang dengan dosis yang sama pada pupuk kotoran hewan lainnya terhadap pertumbuhan dan perkembangan tanaman jagung khususnya pada variabel berat tongkol. Syukur $d k k$ (2000) menyatakan bahwa pupuk kotoran hewan juga sangat mempengaruhi bagian vegegatif tanaman, misalnya luas daun tanaman. Sutriadi $d k k$ (2005) menyatakan bahwa pupuk kotoran hewan yang dapat menyediakan unsur hara selama pertumbuhan tanaman, maka tanaman akan tumbuh dan berkembang secara optimal dan memberikan kemungkinan tanaman menimbun bahan kering yang lebih banyak. 
Hartatik dan Widowati (2005) menyatakan bahwa setiap jenis tanaman membutuhkan jenis dan dosis pupuk kotoran hewan yang berbeda-beda dalam pertumbuhan dan perkembangannya. Disamping itu perbedaan dosis yang diterapkan pada peniliti ini dapat diduga karena perbedaan ternak yang membawa konsekwensi komposisi unsur hara yang dibawa juga akan berbeda-beda seperti pernyataan Sutriadi $d k k$ (2005) yang memberikan contoh pada pupuk kotoran ayam jenis broiler mempunyai kadar hara $\mathrm{P}$ yang relatif lebih tinggi dari pupuk kotoran hewan lainnya yang sejenis karena komposisi unsur hara ini sangat dipengaruhi oleh jenis konsentrat yang diberikan. Syukur $d k k$ (2000) dan Hartatik dan Widowati (2005) menyatakan bahwa semakin tinggi konsentrasi kotoran ayam yang dilarutkan maka kadar $\mathrm{N}$ semakin rendah.

Hasil penelitian ini berbeda dengan yang dilaporkan oleh Sarawa $d k k$ (2014) bahwa perlakuan pemberian pupuk kandang 20 tha $^{-1}$ secara umum memberikan pertumbuhan yang lebih baik dan berbeda dengan perlakuan tanpa pemberian pupuk kandang, akan tetapi memberikan pengaruh yang sebagian besar sama dengan perlakuan pemberian pupuk kandang 10 tha $^{-1}$ terhadap pertumbuhan tanaman kedelai (Glycine Max L. Merr). Kemudan berbeda pula hasil penelitian yang dilaporkan oleh Safuan (2012) bahwa pemberian bahan organik (pupuk kandang kotoran sapi) dosis $10-15$ tha $^{-}$ ${ }^{1}$ dan pupuk Kalium $50-150 \mathrm{~kg} \mathrm{~K}_{2} \mathrm{O}$ tha $^{-1}$ dapat meningkatkan pertumbuhan dan produksi tanaman Melon. Disamping itu perlakuan pupuk kotoran hewan memberikan dampak yang berbeda jika diaplikasikan pada media berbeda, seperti yang dicontohkan oleh Gilbert et al (2008) dalam Abdirrahman $d k k$ (2014) bahwa apabila pemberian bahan organik seperti pupuk kotoran hewan pada tanah berpasir dapat meningkatkan kapasitas tukar kation, siklus hara, kemampuan mencadang air, dan mengurangi erosi.

\section{b. Pengaruh Volume Air}

Tabel 1. Hasil Anova Pengaruh Volume Air Terhadap Variabel Pengamatan Pada Bibit Tanaman Kakao (T. cacao L.) Umur 42 HST.

\begin{tabular}{|c|c|c|c|c|c|c|}
\hline & & Sum of Squares & Df & Mean Square & $\mathrm{F}$ & Sig. \\
\hline \multirow[t]{3}{*}{ TT } & $\begin{array}{l}\text { Between } \\
\text { Groups }\end{array}$ & 304.724 & 3 & 101.575 & 4.753 & .006 \\
\hline & Within Groups & 940.239 & 44 & 21.369 & & \\
\hline & Total & 1244.963 & 47 & & & \\
\hline \multirow[t]{3}{*}{ JD } & $\begin{array}{l}\text { Between } \\
\text { Groups }\end{array}$ & 36.014 & 3 & 12.005 & 5.774 & .002 \\
\hline & Within Groups & 91.482 & 44 & 2.079 & & \\
\hline & Total & 127.496 & 47 & & & \\
\hline \multirow[t]{2}{*}{ PAT } & $\begin{array}{l}\text { Between } \\
\text { Groups }\end{array}$ & 239.494 & 3 & 79.831 & 5.272 & .003 \\
\hline & Within Groups & 666.310 & 44 & 15.143 & & \\
\hline
\end{tabular}

BIOLOGI SEL (VOL 7 NO 1 EDISI JAL-JUL 2018 ISSN 2252-858X/E-ISSN 2541-1225) PAGE 72 


\begin{tabular}{|c|c|c|c|c|c|c|}
\hline & & Sum of Squares & Df & Mean Square & $\mathrm{F}$ & Sig. \\
\hline \multirow[t]{3}{*}{$\mathrm{TT}$} & $\begin{array}{l}\text { Between } \\
\text { Groups }\end{array}$ & 304.724 & 3 & 101.575 & 4.753 & .006 \\
\hline & Within Groups & 940.239 & 44 & 21.369 & & \\
\hline & Total & 1244.963 & 47 & & & \\
\hline \multirow[t]{3}{*}{ JD } & $\begin{array}{l}\text { Between } \\
\text { Groups }\end{array}$ & 36.014 & 3 & 12.005 & 5.774 & .002 \\
\hline & Within Groups & 91.482 & 44 & 2.079 & & \\
\hline & Total & 127.496 & 47 & & & \\
\hline \multirow[t]{3}{*}{ PAT } & $\begin{array}{l}\text { Between } \\
\text { Groups }\end{array}$ & 239.494 & 3 & 79.831 & 5.272 & .003 \\
\hline & Within Groups & 666.310 & 44 & 15.143 & & \\
\hline & Total & 905.804 & 47 & & & \\
\hline
\end{tabular}

Keterangan : TT = Tinggi Tanaman; JD = Jumlah Daun; PAT = Panjang Akar Tunggang

Dari Tabel 1. menunjukkan bahwa perlakuan volume air berpengaruh secara signifikan pada variabel tinggi tanaman, jumlah daun, dan panjang akar tunggang dengan nilai probabilitas $\leq 0.05$ ( $\mathrm{p} \leq 0.05)$ pada bibit tanaman kakao (T.cacao L.) umur 42 HST. Uji Lanjut Duncan dengan selang kepercayaan 95\% $(\alpha=0,05)$ untuk melihat perlakuan volume air yang terbaik terhadap variabel tinggi tanaman dapat dilihat pada Tabel 2.

Tabel 2. Hasil Uji Lanjut Duncan Terhadap Variabel Tinggi Tanaman (cm) pada Bibit Tanaman Kakao (T. cacao L.) Umur 42 HST.

\begin{tabular}{l|l|c|c|r}
\hline \multicolumn{1}{|c|}{ Volume Air } & $\mathrm{N}$ & \multicolumn{2}{c}{ Subset for alpha $=0.05$} \\
\hline \multirow{2}{*}{ Duncan $^{\mathrm{a}}$} & V0 & 12 & 1 & \multicolumn{1}{c}{2} \\
\cline { 2 - 5 } & V2 & 12 & 7.8950 & 12.5392 \\
\cline { 2 - 5 } & V3 & 12 & & 13.9358 \\
\cline { 2 - 5 } & V1 & 12 & & 14.1375 \\
\cline { 2 - 5 } & Sig. & & 1.000 & .431 \\
\hline
\end{tabular}

Keterangan : Perlakuan yang berada pada kolom subset yang sama ditafsirkan tidak ada perbedaan secara signifikan diantara perlakuan tersebut. Sedangkan perlakuan yang berada pada kolom subset yang berbeda, disimpulkan terdapat perbedaan secara signifikan diantara perlakuan yang diujikan.

Untuk melihat perbedaan rata-rata tinggi tanaman berdasarkan kolom subset dapat dilihat pada Gambar 2. 


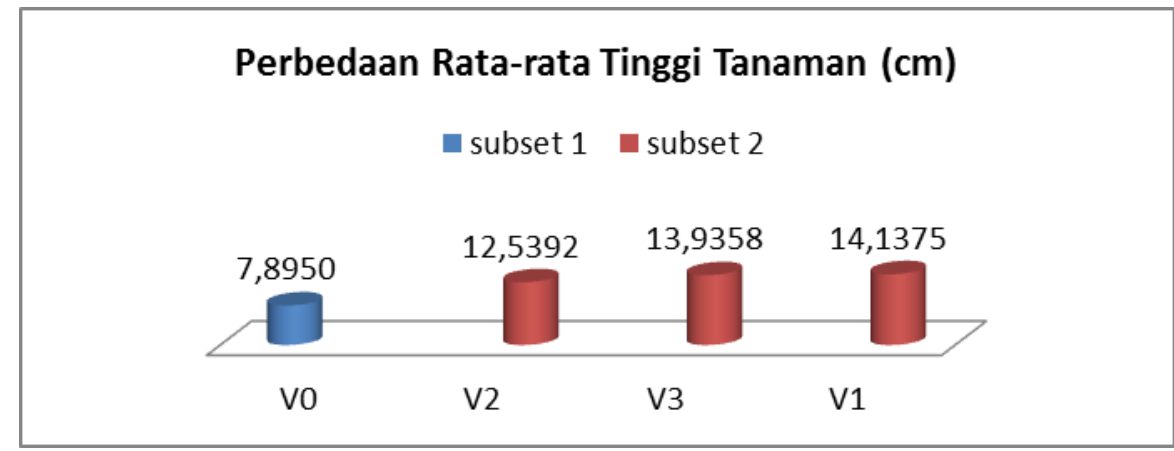

Gambar 2. Grafik Perbedaan Rata-rata Tinggi Tanaman

Dari Tabel 2 dan Gambar 2, memperlihatkan bahwa rata-rata tinggi tanaman untuk volume air $40 \mathrm{ml}$ sebesar $12,5392 \mathrm{~cm}$ dan $60 \mathrm{ml}$ adalah $13,9359 \mathrm{~cm}$, serta yang tertinggi 14,1375 $\mathrm{cm}$ pada perlakuan volume air $20 \mathrm{ml}$ (V1) yang masing-masing berada pada kolom subset 2. Kemudian yang terendah adalah V0 (kontrol) adalah sebesar $7,8950 \mathrm{~cm}$ yang berada pada kolom subset 1. Uji Lanjut Duncan dengan selang kepercayaan 95\% $(\alpha=0,05)$ terhadap variabel jumlah daun dapat dilihat pada Tabel 3.

Tabel 3. Hasil Uji Lanjut Duncan Terhadap Variabel Jumlah Daun pada Bibit Tanaman Kakao (T. cacao

L) Umur 42 HST.

\begin{tabular}{|c|c|c|c|c|}
\hline & \multirow[b]{2}{*}{ Volume Air } & \multirow[b]{2}{*}{$\mathrm{N}$} & \multicolumn{2}{|c|}{ Subset for alpha $=0.05$} \\
\hline & & & 1 & 2 \\
\hline \multirow[t]{5}{*}{ Duncan $^{\mathrm{a}}$} & V0 & 12 & 2.8333 & \\
\hline & $\mathrm{V} 2$ & 12 & & 4.5275 \\
\hline & V3 & 12 & & 4.8883 \\
\hline & $\mathrm{V} 1$ & 12 & & 4.9725 \\
\hline & Sig. & & 1.000 & .482 \\
\hline
\end{tabular}

Keterangan : Perlakuan yang berada pada kolom subset yang sama ditafsirkan tidak ada perbedaan secara signifikan diantara perlakuan tersebut. Sedangkan perlakuan yang berada pada kolom subset yang berbeda, disimpulkan terdapat perbedaan secara signifikan diantara perlakuan yang diujikan.

Berdasarkan perbedaan nilai rata-rata pada variabel jumlah daun terdapat pada Gambar 8.

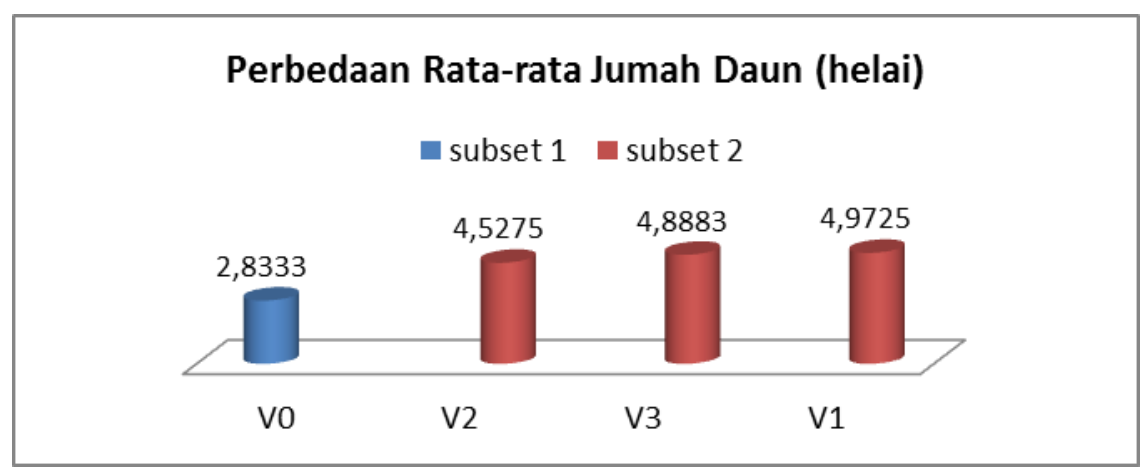

Gambar 3. Histogram Perbedaan Rata-rata Jumlah Daun 
Dari Tabel 3. dan Gambar 3. memperlihatkan bahwa panjang rata-rata jumlah daun untuk volume air $40 \mathrm{ml}$ sebesar 4,5275 helai dan $60 \mathrm{ml}$ adalah 4,8883 helai, serta yang tertinggi 4,9725 helai pada perlakuan volume air $20 \mathrm{ml}$ (V1) yang masing-masing berada pada kolom subset 2. Kemudian yang terendah adalah V0 (kontrol) adalah sebesar 2,8333 helai yang berada pada kolom subset 1. Uji Lanjut Duncan dengan selang kepercayaan $95 \%(\alpha=0,05)$ pada variabel panjang akar tunggang dapat dilihat pada Tabel 4.

Tabel 4. Hasil Uji Lanjut Duncan Terhadap Variabel Panjang Akar Tunggang $(\mathrm{cm})$ Pada Bibit Tanaman Kakao (T. cacao L.) Umur 42 HST.

\begin{tabular}{l|l|c|r|r}
\hline \multirow{2}{*}{} & \multirow{2}{*}{ Volume Air } & \multirow{2}{*}{ Subset for alpha $=0.05$} \\
\hline \multirow{2}{*}{ Duncan $^{\mathrm{a}}$} & V0 & $\mathrm{N}$ & 1 & \multicolumn{1}{c}{2} \\
\cline { 2 - 5 } & V2 & 12 & 7.3192 & \\
\cline { 2 - 5 } & V1 & 12 & 10.3225 & 10.3225 \\
\cline { 2 - 5 } & V3 & 12 & & 12.5833 \\
\cline { 2 - 5 } & Sig. & & & 12.9058 \\
\hline
\end{tabular}

Keterangan: Perlakuan yang berada pada kolom subset yang sama ditafsirkan tidak ada perbedaan secara signifikan diantara perlakuan tersebut. Sedangkan perlakuan yang berada pada kolom subset yang berbeda, disimpulkan terdapat perbedaan secara signifikan diantara perlakuan yang diujikan.

Berdasarkan perbedaan nilai rata-rata pada variabel panjang akar tunggang dapat dilihat pada Gambar 4.

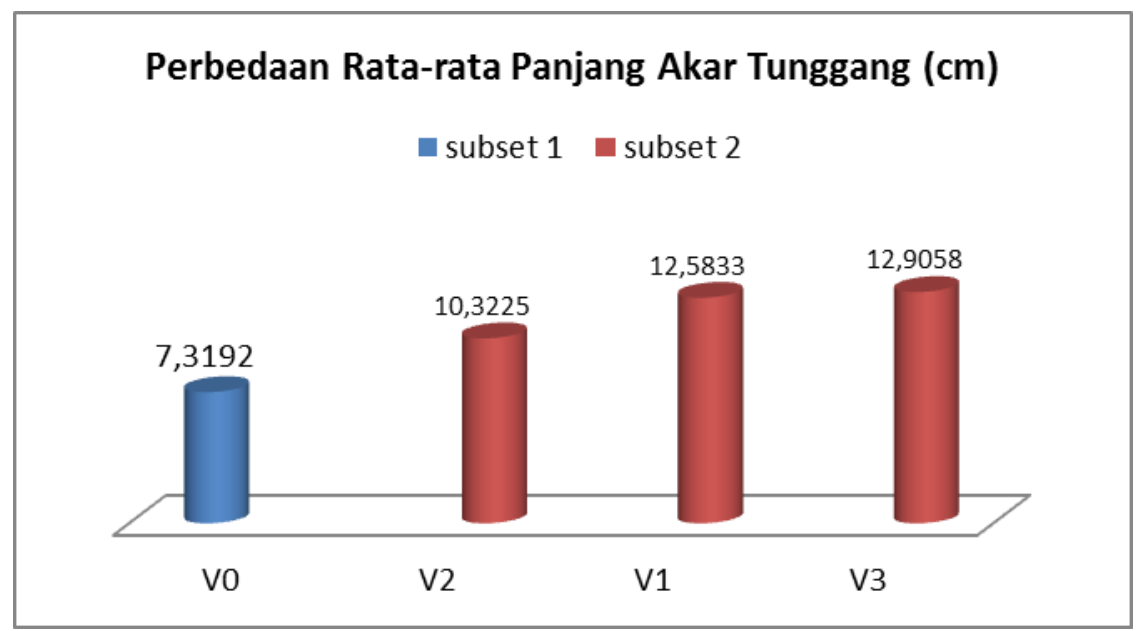

Gambar 4. Histogram Perbedaan Rata-rata Panjang Akar Tunggang

Dari Tabel 4 dan Gambar 4 memperlihatkan bahwa rata-rata panjang akar tunggang untuk volume air $20 \mathrm{ml}$ sebesar $12,5833 \mathrm{~cm}$ dan $40 \mathrm{ml}$ adalah $10,3225 \mathrm{~cm}$, serta yang tertinggi $12,9058 \mathrm{~cm}$ pada perlakuan volume air $60 \mathrm{ml}$ (V3) yang masingmasing berada pada kolom subset 2. Kemudian yang terendah adalah V0 (kontrol) adalah sebesar 7,3192 $\mathrm{cm}$ yang berada pada kolom subset 1 . Hal ini diduga bahwa kemampuan bibit tanaman kakao telah mampu menyerap air dengan baik dari dalam 
tanah sebagai media pertumbuhan. Dugaan ini diperkuat oleh Blair (1979) dalam Agustina (2004) bahwa selain faktor suplai dari dari fase padat dan $\mathrm{pH}$ tanah, maka faktor suplai air juga memegang peranan yang sangat penting dalam mempengaruhi tersedianya unsur hara di dalam tanah atau media tumbuh tanaman karena ketersediaan kandungan air tanah yang rendah dapat mengakibatkan rendahnya konsentrasi unsur hara yang ada dalam larutan tanah, sehingga berakibat pada pertumbuhan optimum tanaman. Kira-kira 70\% atau lebih daripada berat protoplasma sel hidup terdiri dari air (Lakitan, 2008). Nyakpa $d k k$ (1988) dalam Dwiyana $d k k$ (2015) menambahkan bahwa jika tanah atau medium pertumbuhan tanaman berada dalam kondisi air tanah diatas kapasitas lapang menyebabkan kadar oksigen berkurang sehingga pertumbuhan akar akan lambat dan penyerapan unsur hara dan air akan terhambat. Salisbury dan Ross (1997) dalam Dwiyana $d k k$ (2015) menjelaskan bahwa tanaman memerlukan ketersediaan air yang cukup untuk pertumbuhan vegetatif maupun generatif. Hendrata dan Sutardi (2010) mengungkapkan bahwa kebutuhan tumbuhan akan ketersediaan air sangat dibutuhkan yang bertujuan untuk menghindari terjadinya kekeringan dan meningkatkan kelembaban lingkungan yang berperan dalam proses perkecambahan. Olehnya itu, volume air yang sesuai dengan kebutuhan tanaman sangat menentukan proses pertumbuhan dan perkembangan suatu tanaman tidak terkecuali bibit tanaman kakao (PUSLITLOKA, 2010). Mansfield dan Atkinson (1990) dalam Sarawa dkk (2014) menjelaskan bahwa dua macam respons tanaman yang dapat memperbaiki status jika mengalami kekeringan adalah mengubah distribusi asimilat baru dan mengatur derajat pembukaan stomata.

Selain itu hasil penelitian yang dilaporkan oleh Sulistyono (2005) bahwa frekuensi irigasi 1 dan 2 hari sekali menghasilkan tinggi tanaman, jumlah daun, lebar daun, jumlah anakan, dan jumlah anakan produktif lebih tinggi daripada frekuensi irigasi 4 hari dan 6 hari sekali. Hasil-hasil penelitian lain memberi gambaran bahwa efisiensi pemakaian air berkaitan dengan luas daun, dan indeks luas daun, kecepatan pertumbuhan akar, panjang akar, volume akar, elastisitas dinding sel, nisbah tajuk akar, jumlah stomata, dan tipe pertumbuhan (Ritchie,1983; Taylor, 1983; Quisenberry dan Roark, 1976 dalam Anjum dkk, 2013).

\section{KESIMPULAN}

1. Tidak terdapat pengaruh interaksi antara dosis pupuk kotoran hewan dengan volume air siraman terhadap pertumbuhan bibit tanaman kakao (T. cacao L.) umur 42 HST karena diduga terjadi pencucian unsur hara dalam pupuk kotoran hewan akibat tidak seimbang antara ukuran polybag dengan volume air.

2. Tidak terdapat pengaruh dosis pupuk kotoran hewan terhadap pertumbuhan bibit tanaman kakao (T. cacao L.) umur 42 HST. Tetapi berdasarkan nilai rata-rata dari hasil Uji Lanjut Duncan taraf kepercayaan 95\% terlihat bahwa dosis 5 tha $^{-1}$ memiliki 
nilai rata-rata tertinggi terhadap variabel tinggi tanaman, dan jumlah daun, dan panjang akar tunggang jika dibandingkan dengan dosis 10 tha $^{-1}$ dan 15 tha $^{-1}$ karena diduga baru pertumbuhan awal pada bibit tanaman kakao (T. cacao L.) umur 42 HST sehingga belum banyak membutuhkan unsur hara sehingga dosis 5 tha $^{-1}$ diduga telah sesuai kebutuhan pertumbuhan bibit tanaman kakao (T. cacao L.) umur 42 HST.

3. Terdapat pengaruh yang signifikan perlakuan volume air terhadap pertumbuhan bibit tanaman kakao (T.cacao L.) umur 42 HST karena diduga bibit tanaman kakao telah mampu menyerap air dengan baik untuk proses metabolisme. Kemudian berdasarkan Uji Lanjut Duncan disimpulkan tidak ada perbedaan perlakuan antara volume air $20 \mathrm{ml}, 40 \mathrm{ml}$, dan $60 \mathrm{ml}$ kecuali dengan kontrol. Tetapi berdasarkan nilai rata-rata, maka dapat dinyatakan bahwa volume air $20 \mathrm{ml}$ memiliki nilai rata-rata tertinggi pada variabel tinggi tanaman dan jumlah daun, sehingga dapat dinyatakan bahwa volume $20 \mathrm{ml}$ yang paling baik untuk pertumbuhan bibit tanaman kakao klon Sulawesi-1 (S-1).

\section{SARAN}

Perlunya penelitian lanjutan tentang kombinasi berbagai dosis pupuk kotoran hewan dengan berbagai ukuran volume air untuk memperoleh dosis maupun ukuran volume air yang tepat pada berbagai klon tanaman kakao yang telah dibudidayakan oleh petani kakao di Provinsi Maluku.

\section{DAFTAR PUSTAKA}

Afriyeni, Y., Nasir, N., Periadnadi, Junjunidang, 2013. Jenis - Jenis Jamur Pada Pembusukan Buah Kakao (Theobroma cacao L.) di Sumatera Barat, Jurnal Biologi Universitas Andalas (J. Bio.UA) 2 (2) : 124 - 129, ISSN: 2303 - 2162.

Agustina, L., 2004. Dasar Nutrisi Tanaman, Edisi Revisi Cet. Kedua, PT Rineka Cipta, Jakarta

Abdirahman, M.M., Shamsuddin, J., Teh Boon, S.C., Megat, W.P.E., Ali, P.Q., 2014. Effect Of Drip Irrigation Frequency, Fertilizer Source, and Their Interaction and Dry Metter and Yield Componen Of Sweet Corn. Journal of Crop Sciense. No.8 Vol.2, hal. 223- 231.

Anjum, A.S., Ehsanullah, Lanlan, X., Longchang, W., Farrukh, S.M., 2013. Exogenous Benzoic Acid (BZA) Treadment Can Induce Drought Tolerance In Soybean Plants By Improving Gas Exchange And Chlorophyil Contents. Journal of Crop, No.7 Vol.5, hal. 555-560.

Burhanudin, Suhartanto, M.R., Ilyas, Purwantara, 2011. Perubahan Biologi dan Fisiologis Sebagai Indikator Masak Bibit Kakao Hibrida, Jurnal Litri 17 (2), ISSN: 0853 - 8212, Hal. $41-50$. 
Badan Pusat Statistik (BPS), 2012. Potensi Kakao di Maluku: Data Produksi Komoditi Tahun 2012, Sumber Online: www.regionalinvestment.bpkm.go.id diakses tanggal 20 Maret 2014.

Badan Pusat Statistik Provinsi Maluku, 2013. Maluku Dalam Angka, Sumber Online: www.sp2010.bps.go.id diakses tanggal 20 Maret 2014.

Corti, R., Flammer, J., Hollenberg, N.K., Lusches, T.F., 2009. Cocoa and Cardiovascular Health, Journal Circulation, American Heart Association, ISSN: $1524-4539$.

Departemen Perindustrian, 2007. Gambaran Sekilas Industri Kakao, Sumber Online: www.depperin.go.id diakses tanggal 24 Oktober 2014.

Dwiyana, S.R., Sampoerno, Aldian, 2015. Time And Volume Of Water Supply In Seedling Palm Oil (Elaeis gueneensis Jacq.) In Main Nursery, Jurnal Jom Faperta Vol. 2 No. 1 Pebruari 2015, Agrotechnology Department, Agriculture Faculty, University of Riau

Efendi, 2011. Bioetanol Kulit Buah Kakao Menuju Indonesia Mandiri Bahan Bakar Nabati, Sumber Online : www.academi.edu diakses tanggal 3 September 2014.

Gaspersz, V., 1991. Metode Perancangan Percobaan Untuk Ilmu-Ilmu Pertanian, IlmuIlmu Teknik, Biologi, Penerbit CV. Armico, Cet. 1, Bandung.

Henrata, R., Sutardi, 2010. Evaluasi Media dan Frekuensi Penyiraman Terhadap Pertumbuhan Bibit Kakao (Theobroma cacao L.), Jurnal Agrivigor, Vol. 3 No. 1, ISSN: 19795777

Harsini, T. dan Susilowati, 2004. Pemanfaatan Kulit Buah Kakao dari Limbah Perkebunan Kakao Sebagai Bahan Baku PULP dengan Proses Organosolv, Jurnal Ilmiah Teknik Lingkungan, Vol. 2 No. 2.

Hartatik, W., Widowati, L.R., 2005. Pupuk Organik dan Pupuk Hayati, Kode Sumber: Summary-pupuk kandang.pdf

Hendarto E., Suwarso, 2013. Pengaruh Kombinasi Antara Pupuk Kandang dan Urea Pada Tampilan Aspek Pertumbuhan Tanaman Rumput Raja Pada Pemanenan Defoliasi Ke Empat, Bionatura, Jurnal Ilmu-Ilmu Hayati dan Fisik, Vol. 15 No. 2, ISSN 1411-0903

Indonesian Commercial Newsletter (ICN), 2010. Perkembangan Agribisnis Kakao di Indonesia, Laporan Market Inteligence, Sumber Online: www.datacom.co.id/Agri.2010Kakao.html diakses tanggal 20 Maret 2014.

Karmawati, E., Mahmud, Z., Syakir, Munarso, J., Ardana, K., Rubiyo, 2010. Budidaya dan Pasca Panen Kakao, Pusat Penelitian dan Pengembangan Perkebunan, nitro PDF professional, Bogor.

Lestari, P.A., Hanibal, Syamsuddin, S., 2007. Substitution of Inorganic Fertilizer Kascing in Cocoa (Theobroma cacao L.) Seedings in Polybag, Jurnal Agronomi, Vol. 11 No. 2, ISSN: 1410 - 1939. 
Lakitan, B., 2005. Dasar-dasar Fisiologi Tumbuhan, PT RajaGrafindo, Jakarta

Mutryarny, E., Endriani, Lestari, S.U., 2014. Pemanfaatan Urine Kelinci Untuk Meningkatkan Pertumbuhan dan Produksi Tanaman Sawi (Brassica Juncea L.) Varietas Tosakan, Jurnal Ilmiah Pertanian, Vol. 11 No. 2

Maruapey, A., 2011. Pengaruh Jarak Tanam Dan Jenis Pupuk Kandang Terhadap Pertumbuhan Gulma Dan Hasil Jagung Manis, Seminar Nasional Serealia 2011, Kode Sumber : 3bpro11(1).pdf

Nuraini dan Mahata, M.E., 2009. Pemanfaatan Kulit Buah Kakao Fermentasi Sebagai Pakan Alternatif Ternak di Daerah Sentra Kakao Padang Pariaman, Sumber Online: www.forda.mof.org diakses tanggal 12 September 2014.

Prawoto, A.A \& Martini, 2014. Pedoman Budi Daya Kakao Pada Kebun Campur, Pusat Penelitian Kopi dan Kakao Indonesia (Indonesian Coffee and Cocoa Research Institute) bekerja sama dengan Agrofor Sulawesi, Sumber Online: www.wordagroforestry.org/sea/.../bl0049-14-1.pdf

Pusat Penelitian Kopi dan Kakao (PUSLITLOKA) Indonesia, 2010. Buku Pintar Budidaya Kakao, Penerbit AgroMedia, Jakarta Selatan, ISBN: 979-006-317-2.

Sutardi, Hendrata, R., 2009. Respon Bibit Kakao Pada Bagian Pangkal, Tengah, dan Pucuk Terhadap Pemupukan Majemuk, Balai Pengakajian Teknologi Pertanian Yogyakarta, Jurnal Agrovigor, Vol. 2 No. 2, ISSN 19795777

Suntoro, 2001. Pengaruh residu penggunaan bahan organik, dolomit dan $\mathrm{KCl}$ pada tanaman kacang tanah (Arachis hypogeae) pada Oxic Dystrudept di Jumapolo Karanganyar, Jurnal Habitat, 12 (3): 170-177

Sutedjo, 2002. Pupuk dan Pemupukan, Penerbit PT Rieneka Cipta, Jakarta

Sarno, 2009. Pengaruh Kombinasi NPK dan Pupuk Kandang terhadap Sifat Tanah dan Pertumbuhan serta Produksi Tanaman Caisim, Jurnal J. Tanah Trop., Vol. 14, No. 3, 2009: 211-219 ISSN 0852-257X

Sumarno, 1992. Pengaruh Teknologi Cadangan Air Dekat Perakaran Di Lahan Kering Terhadap Pertumbuhan Sengon Buto (Entrolobium cyclocarpum), Fakultas Pertanian Universitas Abdurachman Saleh, Situbondo, Kode Sumber: 2014-0330-66 BAB 4.pdf

Salisbury, F.B. \& C.W. Ross, 1992. Plant Physiology. 4thEd. Wadsworth Publishing Company Bellmount, California (Terjemahan Dian R. Rukman dan Sumaryono: Fisiologi Tumbuhan, Jilid 2- Biokimia Tumbuhan, Edisi Keempat, Penerbit ITB Bandung, Bandung, ISBN 979-8591-27-5

Sutriadi, M.T., R. Hidayat, S. Rochayati, dan D. Setyorini, 2005. Ameliorasi Lahan Dengan Fosfat Alam Untuk Perbaikan Kesuburan Tanah Kering Masam Typic Hapludox Di Kalimantan Selatan. hlm. 143-155 Dalam Prosiding Seminar Nasional Inovasi Teknologi Sumber Daya Tanah dan Iklim. Buku II. Bogor, 14- 
15 September 2004. Pusat Penelitian dan Pengembangan Tanah dan Agroklimat, Bogor.

Syukur, A., Titi Wurdiayani, dan Udiono, 2000. Pengaruh Dosis Pupuk Kandang Terhadap Pertumbuhan Turus Nilam Di Tanah Regosol Pada Berbagai Tingkat Kelengasan Tanah. hlm. 465-476 Dalam Prosiding Kongres Nasional VIII HITI. Pemanfaatan Sumberdaya Tanah Sesuai dengan Potensinya Menuju Keseimbangan Lingkungan Hidup dalam rangka Meningkatkan Kesejahteraan Rakyat. Buku I. Bandung 2-4 November 1999.

Sarawa, Arma, M.J., Mattola, M., 2014. Pertumbuhan Tanaman Kedelai (Glycine Max L. Merr) Pada Berbagai Interval Penyiraman Dan Takaran Pupuk Kandang (Vegetative Growth Of Soybean (G,lycine Max L. Merr) At Different Irrigation Frequencies And Manure Dosages), Jurnal Agroteknos, Vol. 4 No. 2, hal. 7886, ISSN 2087-7706

Safuan, L., 2012. Pengaruh Bahan Organik Dan Pupuk Kalium Terhadap Pertumbuhan Dan Produksi Tanaman Melon (Cucumis melo L.), Jurnal Agroteknologi, No.2 Vol. 2, hal. 70-76.

Sulistyono, E., Suwarto, Ramdiani, Y., 2005. Defisit Evapotranspirasi sebagai Indikator Kekurangan Air pada Padi Gogo (Oryza sativa L.). Buletin Agronomi, No. 33 Vol.1, hal. 6-11.

Tsobeng, A., Tchoundjeu, Z., Lazare, K., Asaah, 2011. Effective Propagation of Diospyros crassiflora (Hiern) using twig cuttings. Internasional Juornal of Biosciences (IJB), ISSN: 2220-6655, Vol.1. No.4, p. $109-117$.

Tsobeng, A., Asaah, E., Makueti, J., Tchoundjeu, Z., Damme, P.V., 2013. Propagation of Pentaclethra macrophylla Bent (Fabaceae) Through Seed and Rooting of Leafly Stem Cuttings. Internasional Juornal of Agronomy and Agrcultural Research (IJAAR), ISSN: 2223-7054, Vol.3, No.12, p. 10 - 20.

Wulan, S.N., 2001. Kemungkinan Pemanfaatan Limba Kulit Buah Kakao (Theobroma cacao L.) Sebagai Sumber Zat Pewarna ( $\beta$-Karoten), Jurnal Teknologi Pertanian, Vol.2 No. 2, Hal. 22-29. 